\title{
Creating Corporate Culture in CONTEXT WITH STANDARDS ISO 9001: 2015
}

\author{
Jaromíra Vaňová, Iveta Paulová, Miroslav Rusko \& Edita Hekelová
}
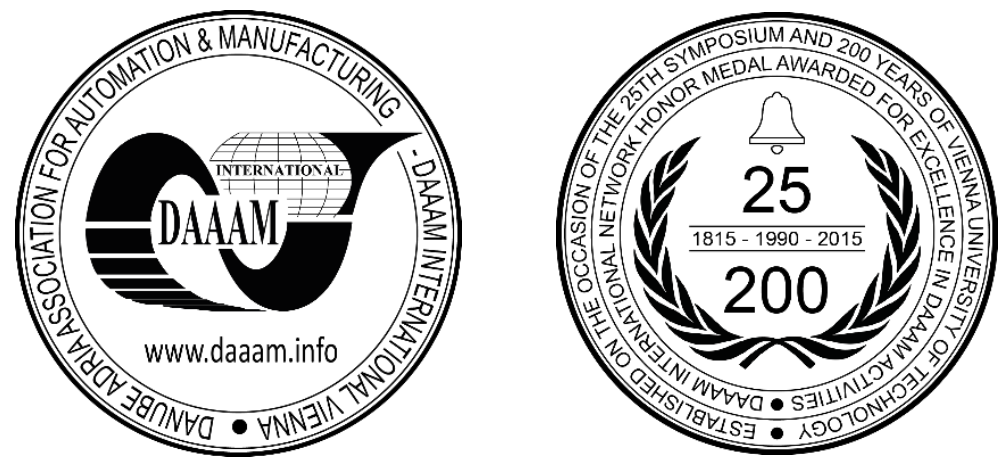

This Publication has to be referred as: Vanova, J[aromira]; Paulova, I[veta]; Rusko, M[iroslav] \& Hekelova, E[dita] (2017). Creating Corporate Culture in Context with Standards ISO 9001: 2015, Proceedings of the 28th DAAAM International Symposium, pp.0274-0279, B. Katalinic (Ed.), Published by DAAAM International, ISBN 978-3-902734-112, ISSN 1726-9679, Vienna, Austria

DOI: $10.2507 / 28$ th.daaam.proceedings.037

\begin{abstract}
Corporate culture promoting the quality is focused on employees' behaviour concentrating on the continuous improvement of the processes' and products' quality. The final objective is to meet the changing requirements of customers at an appropriate management efficiency of the organization, which lead to a competitiveness. Any organization that is committed to the transformation of quality management or environs in accordance with the new requirements, has to create such environs in which the involvement of workers in the effective management of changes and new requirements is supported. The basic focus of the organization at the quality promotes a culture, which results in behaviour, opinions, activities and processes that add a value to the fulfilment of the needs and expectations of customers and other relevant stakeholders. The paper focuses on identifying changes in corporate culture by strengthening factors that are the result of a company's focus on fulfilling the requirements of standards ISO 9001:2015.
\end{abstract}

Keywords: Corporate Culture; Standards ISO 9001:2015; Quality System Management; Leadership

\section{Introduction}

Quality is ultimately defined by customers. There is significant literature available on how to measure quality and value as perceived by customers. In virtually every analysis, a major component of customer satisfaction is the ability of the company to provide a competitively priced product into which quality is designed, built, marketed, and maintained.

The aim of the organization is to meet the needs and expectations of customers as well as the other stakeholders and simultaneously to reach, maintain and improve the overall performance and the capacity of the organization. The surveys of economically successful enterprises show that the soft factor "corporate culture" contributes to their success. The change of the corporate culture belongs to some complex management tasks. Any organization that is committed to the transformation of quality management or environs in accordance with the new requirements (in context with ISO 9001:2015), has to create such environs in which the involvement of workers in the effective management of changes and new requirements is supported.

Total quality is the total systems approach (not a separate area or program) and an integral part of any high-level strategy; it works horizontally across functions and departments; involves all employees, top to bottom; and extends backwards and forwards to include the supplier and the customer chains. [1]. 
The social system has a significant impact on motivation and the ability to implement new ideas; it addresses corporate culture, structure, rewards, teamwork, values, and the creativity of individuals and groups. The social system is influenced by the values of the founders, leaders, families, peers, and supervisors, as well as group behaviours. Some authors are of the opinion that a certain type of corporate culture can help to maintain the long-term performance of the enterprise and be a source of competitive advantage.

That is why we also carried out secondary research of already existing studies available from subject area, in addition to the structured interviews and a questionnaire survey as a part of our project.

Our survey in the area was carried out from May 2016 to October 2016. For the purposes of the processing of this article only the questions that were related to the selected area of the present state of the corporate culture in organizations, which began with the transformation of the new standards ISO 9001:2015 were selected and used.

\section{Corporate culture}

Corporate culture, in the sense of a complicated and internally structured system is created and developed continuously in the company. Its creation in any particular company is timely compliant with the company foundations. As a company grows and develops gradually, so its culture is created, developed and continually changed (supplemented and filtered) also its culture 2010) [2].

The notion of corporate culture is defined by several authors. However, all definitions have the same characteristics and essence of: "...the shared philosophies, ideologies, (values, assumptions, beliefs, expectations, attitudes and standards ... how to make decisions and to solve problems..." [3]. In the case of a corporate culture that is essential for the transformation of new approaches to the management of quality, it is necessary for a top manager to be in the role of a leader, to be a personality that leads the way, to be a motivator and coach in the organization, to implement the creative management style and both acknowledges and objectively appreciates the achievements reached, the behaviour of individuals but also of the whole team [4].

At present, the transformation of ISO 9001:2015 standards becomes reality, that is affecting, in particular, some changes in approaches to the management of quality in areas such as the change of behaviour of the leaders, change of management (with respect to the risks) with an emphasis on continuous improvement, creativity and innovation. From all this it can be concluded that there is a change in the corporate culture of the organization. Continuous improvement is the basement of the corporate culture, which provides the organization of the management aimed at constantly improving, and educates employees to search for ways of possibilities for improving and solving some deficiencies. The corporate culture of a particular organization must be able to cope effectively with the changes in the organization. The characteristic features of a corporate culture that supports the transformation of requirements for quality management system and/or environmental management system are as follows:

- involved, active and competent employees identified with the organization objectives which they effectively perform,

- $\quad$ individual responsibility for performance of the tasks and resolving disagreements [5].

It cannot be automatically assumed that mere creation of a corporate culture is responsible for the success of the enterprise and its development. There must occur a mutual interaction and linking of corporate strategy - corporate culture - corporate structures - corporate communication. [6]

In this context, the theme of the corporate culture and related questions of quality of work, is getting into the centre of economic interest and is still more often associated with possibility that may increase competitive ability of company as well as satisfaction of employees.

\section{Some of the requirements for the quality management system}

The new standards ISO 9001: 2015 substantially extended the requirements to the top management- leaders. The top management has to perceive and quickly respond to changes in the business environs, to take an interest and make survey of stakeholders that can influence this business environs. New challenges and opportunities require 101 for the leaders to have a more sensitive approach to search and cope up with risks, the ability to respond to changes and to be creative enough or at least flexible [7]. It is further specified that the organizational changes must be implemented in a planned way. The most common changes can be those changes induced by the maintenance and improvement of the quality management system, the changing of some processes, internal and external aspects. Typical examples of organizational changes may be the introduction and take-up of new technologies, the changes in significant external provider, a change of the place of performance of services, major personnel changes, etc.

Employees of the organisation represent resources that may directly or indirectly influence their growth and the sustainability of their performance. The aim of each organization is to support its operation comprehensively. The management of the organization includes particularly the setting of the whole management system of the organization-setting the values and rules of the organization, setting up an organizational structure, resource management, processes and performance settings. For this reason, a basic requirement in the framework of the quality management system of the organization is to determine the responsibility of leaders for systematic and organized using of the knowledge, which is essential to the growth and wealth of the company. This is related to the requirement of continuous development of knowledge 
of all those employees who may need them [8]. In this case, we perceive the knowledge as a set of abilities, skills, experience, intuition, rules, and principles, personal notions of a specific person or a group of people. The requirement of the standards ISO 9001: 2015 is that the top management (leaders) have to assess how to primarily identify and continuously acquire the knowledge needed to meet the expected and anticipated future needs, to assess the knowledge requirements along with the current need of the staff knowledge, to assess the form of knowledge and the extent to which knowledge is identified and protected.

Communication in the framework of the quality management system increases the involvement of the people and improves the understanding of management and approach of the organization; it allows to clarify the needs and expectations of customers. Communication is a two-way process. Sharing information and subsequent feedback obtaining are the cornerstones of a good corporate culture [9].

\section{Results of the survey dealing with current situation in fulfilment of the requirements of ISO 9001: 2015 standards in enterprises in Slovakia}

As part of the project solution has been realized research through questionnaire about actual situation in applying principles of quality management in enterprises and comparison how are fulfilled some requirements in several enterprises in Slovakia. We carried out a survey on a sample of 125 enterprises in Slovakia. $40 \%$ of them was large and $60 \%$ medium sized enterprises.

Basic mathematical methods were used for questionnaires evaluation. We applied methods of analysis and synthesis for obtained information and various aspects of research problems solutions discussing. These methods were used to sort and summarize identified data. In this article we would like to present partial results of our survey focused on this issue.

The requirement for a successful and transparent application of the organization strategy is directed to the interlacing of the strategy at the lower levels through the objectives and quality policy, which can be fulfilled in the case, if there is a systematic approach created to the monitoring of the objectives achievement at various levels of governance, which must be all the key employees informed with. The level of corporate culture is determined in particular by leaders, who define responsibilities and powers for individual roles. It also includes a way of planning, managing, controlling and especially communicating. The survey revealed the level of leadership competencies for the successful transformation of the requirements of ISO 9001: 2015.

Figure 1 shows the difference between large and medium-sized organizations. Defined responsibilities and powers for effective organization management are better perceived by large organizations. Up to $77 \%$ of large organizations claim that organizational authorities and responsibilities are clearly, assigned, communicated and understood. Results from middle organizations point to the ambiguity of the approach to a clear definition of responsibilities and competences, and in particular communication. It is therefore necessary to draw attention to the unequivocal determination of competences for leaders at all levels of management as they are the carriers of the changes that need to be made in implementing ISO 9001: 2015 standards.

One of the key tasks of the leader in organizational changes, and thus in the transformation of the new requirements of ISO 9001: 2015, is to be an example to other employees, an authority that can directly present the company's goals of change. Creating trust between management and other employees is a guarantee of success. For this reason, we have looked at these aspects in large and medium-sized organizations.

Are organizational authorities and responsibilities for the relevant roles (including quality areas) assigned? (the data are in \%)

Organizational authorities and responsibilities are clearly assigned, communicated and understood.

Organizational authorities and responsibilities are assigned, but not completely understood.

Organizational authorities and responsibilities are not entirely clear for all relevant roles.

They are appointed representatives of management and specified requirements for responsibility and authority

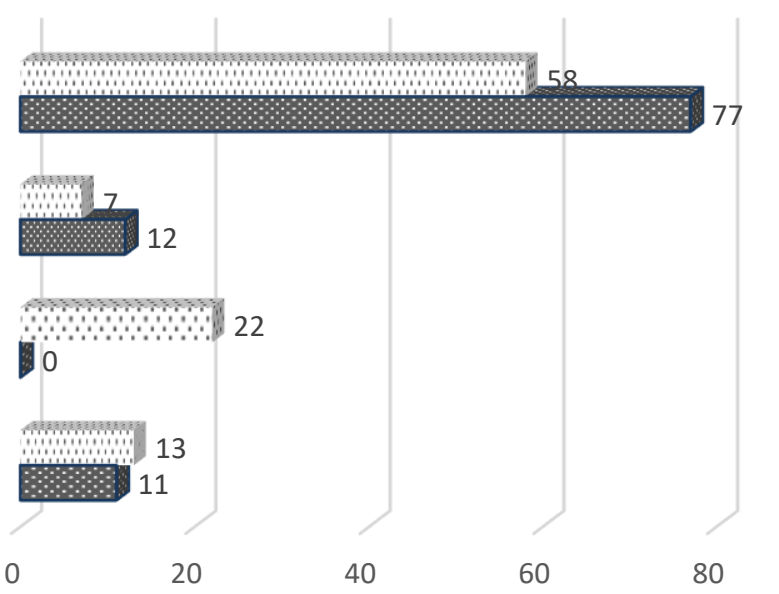

medium-sized companies large companies

Fig. 1. Assigning responsibilities and authorities for relevant roles in the organization 
Figure 2 presents the results of the survey and points to the fact that in 59\% of the top management organizations has found its way to people and communicates with them openly. In middle organizations, $40 \%$ of top managers have found a way to people away and talk openly about the organization's intentions, but the same percentage is at the stage of looking for employees and not always communicating them.

Some organizations still have an authoritative style of governance (22\% in medium-sized organizations and $11 \%$ in large organizations), which is not positive for changes in organizations. Employees are not motivated to change and managing changes in the organization is inefficient and cumbersome.

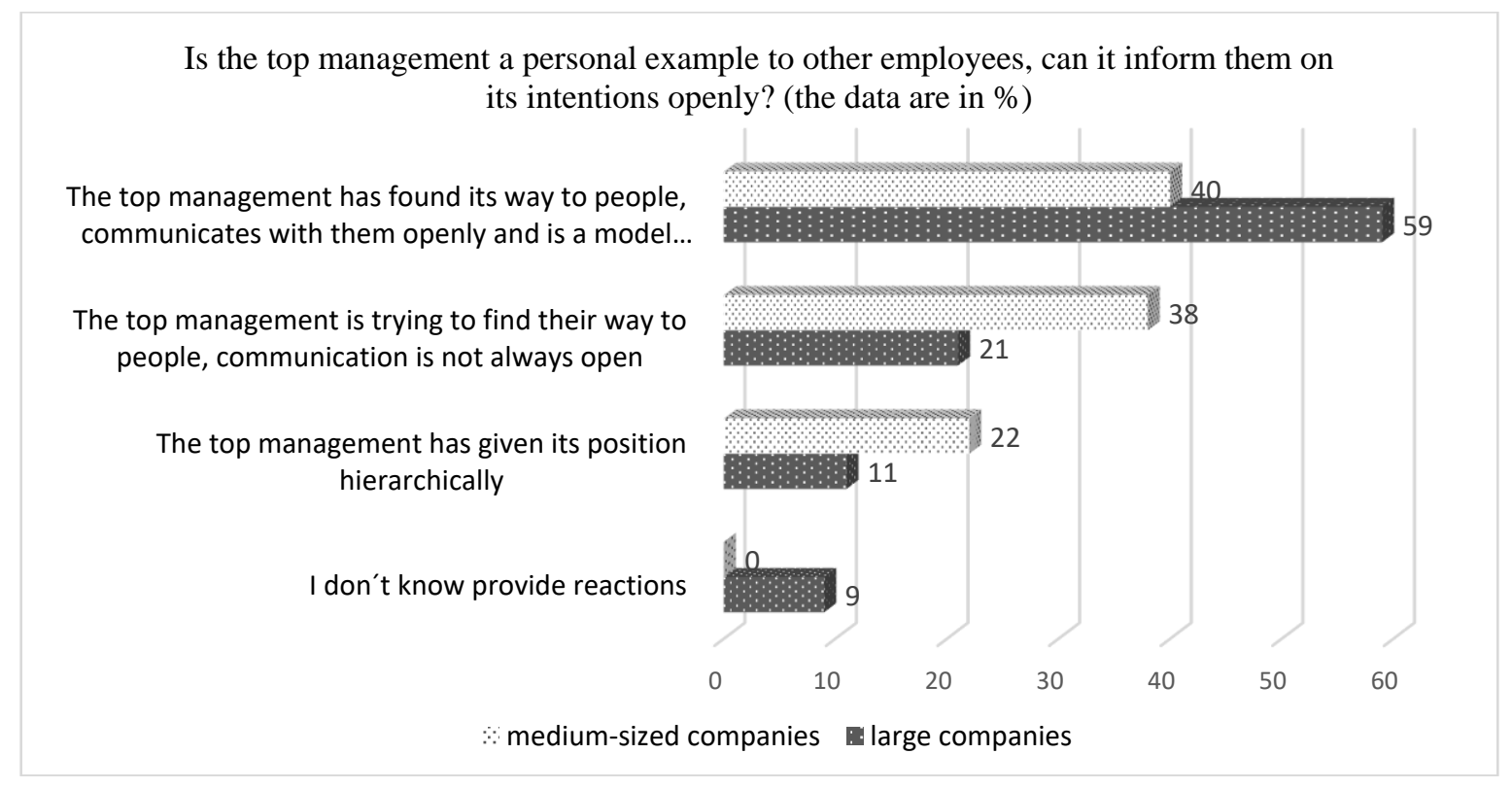

Fig. 2. Results of research about perceiving top managers in the enterprises (in \%)

In addition to the need for effective communication of top managers with employees, it is essential to have effective communication with key stakeholders as well. Stakeholders are an essential part of an effective transformation of ISO 9001: 2015 standards in organizations. They share their insights into improving organizations' outcomes and perceiving the organization's external environment.

As it can be seen from Figure 3 in large organizations, levels of effective communication within the organization are equally balanced and $44 \%$ of stakeholders are interested in stakeholders and only $28 \%$ in medium-sized organizations. In medium-sized organizations, the flow of information in the organization is highest, feedback and verification of customer understanding is random. However, a third of large and medium-sized communication organizations take place internally with the management interface and outsourced employees with customers.

According to Sivri, Hennersdorf, \& Krallmann (2016) "Research highlights that employees' awareness and involvement within the implementation are crucial success factors." [10]

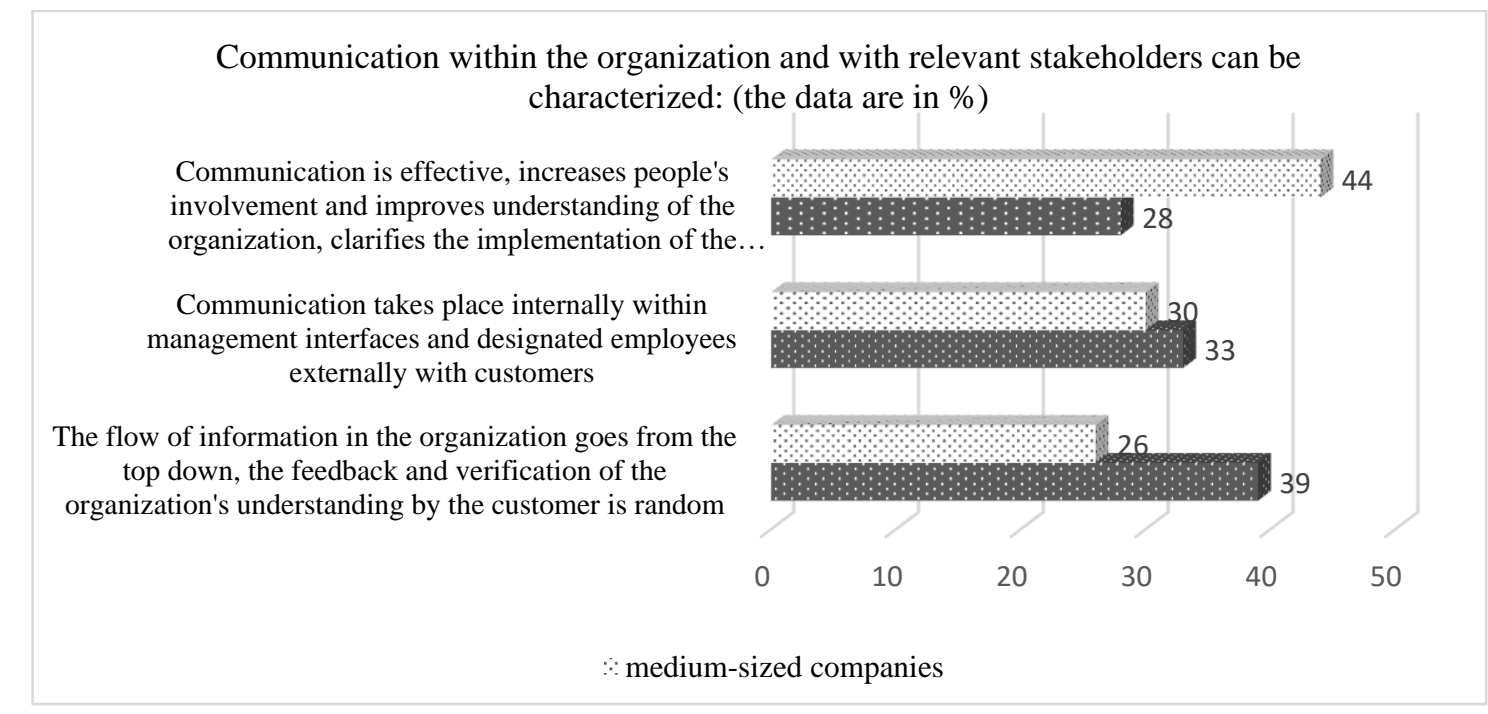

Fig. 3. The internal and external communications in organizations involved in research 


\section{Discussion}

The organizations have to adapt to the requirements of the international market and, changes of the management methods and business philosophy in order to withstand any tough competitive struggles and to achieve a sustainable development. In all areas of economic and social life there are increased demands on corporate behaviour and there is a growing interest in maintaining and improving the product quality, the environment and safety at work.

Business performance is composed of the performance of the employees. Employees with their work, activities, work attitude and their performance should contribute to reaching company's set goals and required business performance. Successful company performance at the market is influenced by potential of all company employees and managers [11]. Improvement of managerial work is one of the main tasks of human resource management in companies. It is due to the fact, that only a well-prepared manager can provide desired results. Main development requirement therefore is to educate the managers to be qualified leaders who can focus on strategically important issues and effectively engage employees to provide required performance. Recent trends bring a competency model approach to the management and human resource development

The organization identifies, develops and keeps competences of employees. If the organization creates a structure to allow its employees continuously develop their own competences, assume greater responsibility and show more initiative, then the employees contribute to the development of the workplace. Employee involvement is to create and environment in which employees have influence on the decisions and actions that affect their work. It involves creating a culture that supports the mission, vision, and values of the organization in practice. [12]

There are several factors that affect the performance of the company and one of them is a corporate culture. A suitable shaping corporate culture is achieved by working employee satisfaction, what inherently leads to the achievement of the business objectives and desired performance.

Through the corporate culture, company forms working environment and try to make the employees identify themselves with the preferred corporate values and ideas.

The survey shows that the challenge is to embrace and understand the soft factors and to define them as a concept that can be used at adapting the ISO 9001: 2015 standards. Because of this, it is necessary to deal with the question, what are the characteristics of corporate culture at the transformation of individual standards requirements.

The questions that can be asked, are e.g.: What characters and characteristics should a culture have and how they can be used as a tool of governance affecting the effective change of approaches, in accordance with the required standards? The exact rules and fixed and defined structures have a negative impact on creativity and motivation of employees, which are an important prerequisite for the first stage of the change at the transformation of standards.

Changes of the structure mean a change in the formal arrangements of the organization, modification in the extent of centralization or decentralization, authority, work descriptions, etc. Technological changes relate to the machinery and equipment used, and to the ways and methods of work performance. Changes in the field of people interfere with approaches of people to work, their expectations, their perception of work and organization, which is reflected in their behaviour.

In further research we will focus on how an organization enables its employees to use their full potential in accomplishing organizational objectives and how the organization maintains an environment that promotes performance excellence, full participation, and personal and organizational growth. Accomplishing this requires a close coupling between the leadership system and human resource system to enable defining and implementing the methods and structures needed to lead the organization in its strategic direction.

In the next step we want to find answers to questions:

- How do managers motivate employees to develop and utilize their full potential?

- How do managers ensure effective communication, cooperation, and knowledge/ skill sharing across work units, functions, and locations, as appropriate?

- How do managers identify characteristics and skills needed by potential employees?

- How do companies determine the key factors that affect employee well-being, satisfaction and motivation?

An organization must have approaches for enhancing employee well-being, satisfaction, and motivation based upon a holistic view of its entire workforce.

Measuring how well employees understand the connection between quality and customers can also show what an organization needs to do to achieve an organizational customer focus and competitiveness in the market

\section{Conclusions}

In addition to guiding and coordinating internal and external management and organisational processes in company, management of company has to nowadays meet also other important tasks. They have to harmonize profitability, humanity and legitimacy. If company management wants to be successful in markets with increasing competition, they should have set objectives to which it's heading, but also the values that will be respected for achievement of these objectives. 
Analysis confirmed that humanely and effectively created and shaped corporate culture as well as model, exemplar behaviour of managers can be included among the crucial factors in the success of many companies.

Each organization that is committed to the implementation of new approaches of the organization to the requirements of the standards ISO 9001: 2015 must create such an environment in which the employees' creativity is supported, which results in the possibility of different forms of improvement. Enterprises are trying to ensure higher productivity, greater employee satisfaction and the sustainability of the organization in relation to the environment through building a favourable corporate culture. A key role in this is met by leaders of the organization, who are changing also their roles in organization including the management style. The communication and its form and the way that should be efficient for the emerging environs are also important. It is essential to defuse an outdated management approach through commands and controls, and to look at people in what their strengths are and use it for the benefit of the organization. Satisfied and happy employees have a great impact on the organization's performance and profits. The human potential is a new competitive advantage [13].

The survey results indicate that there is a need to create a systemic approach in the sense of the current corporate culture analysis (including a selection of characteristics, marks and sphere of analysis), the proposal for a corporate culture that the way of communication within the organization, especially in medium-sized organizations. For this reason, it is necessary to focus on reconsidering the way of communication between the different levels of management, but especially the efficiency and the way of communication between the management and the employees. Sharing information on time and openly is a key aspect of the effective transformation of ISO 9001: 2015 standards. It is necessary to create a pro-innovative corporate culture where it will be possible to design impetus, improve and, in particular, discuss and improve at all levels of management.

For effective communication with stakeholders, it is necessary to create a database of key stakeholders and identify their relationships and the impacts of cooperation. The most important area is the change of managers' leadership competencies, where the personality features of the manager are especially important.

\section{Acknowledgements}

The paper is a part of research project VEGA 1/0990/15 "The readiness of industrial enterprises to implement the requirements of standards for quality management systems ISO 9001:2015 and environmental management systems ISO 14001:2014."

\section{References}

[1] Edosomwan, J. A. (1995), Organizational Transformation and Process Reengineering, St. Lucie Press, St. Lucie, FL.

[2] Blašková, M.: (2010). Systémové poňatie podnikovej kultúry. System concept of corporate culture. In: Ekonomika a manažment podnikov 2010 : Medzinárodná vedecká konferencia. Zvolen, 5.-6. 10.2010. - Zvolen : Technická univerzita vo Zvolene, 2010. - ISBN 978-80-228-2150-6. - pp. 168-175

[3] Killman, R., Saxton, M. J., Serpa, \& all. (1985). Gaining Control of the Corporate Culture. San Francisco, London, JosseyBass Publishier, ISBN 0-87589-666-9.

[4] Zgodavova, K., Kisela, M. \& Sutoova, A. (2016). Intelligent approaches for an organisation's management system change", The TQM Journal, Vol. 28 Issue: 5, pp.760-773, https://doi.org/10.1108/TQM-10-2015-0130

[5] Lukašová, R. \& Nový, L (2004). Organizační kultura.Praha: Grada Publishing, ISBN 80-247-0648-2

[6] Gyurák Babel'ová, Z. Effectiveness of investments into human resources development in Slovakia. Lódź : KSIEZY MLYN Dom Wydawniczy Michal Kolinski, 2011. 95 s. ISBN 978-83-7729-114-6.

[7] Composite authors of CAQ (2016). Komentované vydání ČSN EN ISO 9001:2016. Editor: Česká společnost pro jakost

[8] Zgodavova, K., Hudec, O. \& Palfy, P. (2017). Culture of quality: insight into foreign organisations in Slovakia. Total Quality Management \& Business Excellence Vol. 28, Iss. 9-10, 2017. DOI: 10.1080/14783363.2017.1309120.

[9] Paulová, I. \& Vaňová, J. (2015). Change of the corporate culture in transforming of ISO 9001: 2015 and ISO 14001: 2014. In Journal of Environmental Protection, Safety, Education and Management. Vol. 4, No. 8 (2016), s. 100-104. ISSN 1339-5270.

[10] Sivri, S; Hennersdorf, S. \& Krallmann, H. (2016).Enhanced Method for Quality-fit (ISO 9001) Operations within the Automotive Industry, Proceedings of the 26th DAAAM International Symposium, pp.0614-0619, B. Katalinic (Ed.), Published by DAAAM International, ISBN 978-3-902734-07-5, ISSN 1726-9679, Vienna, Austria DOI: 10.2507/26th.daaam.proceedings.083

[11] Vaňová, J., Gyurák Babel’ová, Z. \& Holková, A (2009). Company success dependency on management. In Annals of DAAAM and Proceedings of DAAAM Symposium 2009 : Vol. 20, No. 1. s.0741-0742. ISSN 1726-9679. V databáze: WOS ; SCOPUS.

[12] Paulová, I; Vaňová, J.\& Dóza, P. (2016). Standard of fulfilment of requirements in the application of TQM in Slovak republic, Chapter 38 in DAAAM International Scientific Book 2016, pp.435- 446, B. Katalinic (Ed.), Published by DAAAM International, ISBN 978-3-902734-09-9, ISSN 1726 -9687, Austria, Vienna, Austria DOI: 10.2507/daaam.scibook.2016.38

[13] Muhlfeit, J. \& Costi, M. (2017). Pozitívni leader. Albatros Media a.s. Praha. ISBN 978-80-265-0609-6 